\title{
THE EFFECTS OF IPA II PRE-ACCESSION ASSISTANCE INSTRUMENTS IN BOSNIA AND HERZEGOVINA, KOSOVO, AND TURKEY
}

\author{
Suada A. Džogović \\ Anita Cucović** \\ Suada Ajdarpašic ${ }^{* * *}$ \\ Enes Hamzagic ${ }^{* * * *}$
}

Received: 18. 2. 2021

Professional paper

Accepted: 7. 10. 2021

UDC 339.96(497:4-67EU)

DOI https://doi.org/10.30924/mjcmi.26.2.14

\begin{abstract}
Provided that one of the goals of the European Union (EU) is the economic development and possibility of integration by implementing fundamental reforms through an adequate strategic approach, this paper aims to determine the impact of the EU policy and the Instrument for PreAccession Assistance (IPA Fund) on the international business environment with special emphasis on Bosnia and Herzegovina, Kosovo, and Turkey. It is obvious that the EU not only provides assistance to candidate countries but also contributes to the stability, security, and prosperity of beneficiary countries. However, by adopting this approach, the EU imposes certain changes in the instruments of financial support. Namely, by launching the IPA II programme it surpassed IPA I, covering five priority areas as the key segments of development.
\end{abstract}

Abstract

\section{INTRODUCTION}

The European Union takes precedence in terms of the value of its financial
It has been shown that this support programme is of great importance for the development of the countries covered in this study. Our research also indicates that IPA funding aids in the political and economic reforms of transition countries, preparing them for the rights and duties that come with the Union membership. Secondary data available on the official website of the European Union were used in this study. The hypothesis is confirmed by quantitative data analysis showing a significant impact of the IPA II programme on defined sectors in Bosnia and Herzegovina, Kosovo, and Turkey.

Keywords: $E U$, countries in transition, influence, international business environment, IPA II program

assistance in the Western Balkan countries and Turkey. IPA (Instrument for Pre-Accession Assistance) funding has been designed to provide non-refundable

* Suada A. Džogović, PhD, Assistant professor, University of Peja, Faculty of Business, Str. Eliot Engel, 30000 Peja, Kosovo. Phone: +38349441141, Email: suada.dzogovic@unhz.eu, ORCID: https://orcid.org/0000-00032651-925X

** Anita Cucović, PhD, Lecturer, University of Prizren, Faculty of Computer Science, Str. Rruga e Shkronjave, 20000 Prizren, Kosovo. Phone: +38349624791, Email: anita.cucovic@uni-prizren.com

*** Suada Ajdarpašić, PhD, Teaching assistant, University of Peja, Faculty of Business, Str. Eliot Engel, 30000 Peja, Kosovo. Phone: +38349687970, Email: suada.ajdarpasic@unhz.eu, ORCID: https://orcid.org/0000-00029692-6953

${ }^{* * * * *}$ Enes Hamzagić, PhD, Member of the GRM laboratory, Université Côte d'Azur, IAE Nice Graduate School of Management, Str. 5 rue du 22e B.C.A, 06300 Nice, France. Phone: +381638780988, Email: enes.hamzagic@ etu.univ-cotedazur.fr 


\section{Journal of Contemporary Management Issues}

pre-accession assistance to candidate nations and future EU members. IPA brings together four pre-accession instruments used before 2007: PHARE, SAPARD, ISPA, and CARDS. IPA II, developed in cooperation with beneficiaries, established a new structure for delivering pre-accession support from 2014 to 2020 . IPA encompasses candidate countries (North Macedonia and Turkey) and potential candidate countries (Albania, Bosnia \& Herzegovina, Montenegro, Serbia and Kosovo). According to Antonopoulos \& Bachtler (2014), EU pre-accession aid initiatives, such as the current IPA, have attempted to help national governments create structures for national coordination of the EU policy. The aim of this paper is to compare the level of investment of the European Union through the IPA II instrument in Bosnia and Herzegovina, Kosovo, and Turkey. It also seeks to examine the relationship between IPA II investment in these countries, on the one hand, and, on the other hand, investment in the sustainable development of the same countries.

\section{IPA II INSTRUMENT FOR PRE-ACCESSION ASSISTANCE 2014-2020}

The strategic emphasis of the IPA II programme is its most significant aspect. National strategies are unique planning documents that are created for each user over a seven-year period. They should enable greater user ownership through the integration of the reform and development plans. The multinational strategic document also addresses the priorities of regional or territorial cooperation. In this sense, IPA II attempts to implement changes in predefined areas. These areas encompass topics connected to the expansion plan, such as democracy and governance, the rule of law, and development and competitiveness. This sectoral strategy encourages institutional reforms that will enhance the sector and bring it closer to EU standards. In other words, these improvements indicate a move toward focused support, with an emphasis on efficiency, sustainability, and outcomes. Such an instrument should allow the beneficiary countries to enjoy the same rights and living standards as the citizens of the European Union. Belloni (2009) states that "integration into the European institutions can provide an avenue for increasing contacts among the countries in the region, and contribute to de-politicizing potentially explosive border issues". Juncos (2012) also claims that the formation of the Stability Pact mirrored this goal.

Furthermore, financial aid from the EU has focused on this objective. One component of the IPA, for example, is the "CrossBorder Cooperation." When comparing IPA II to other assistance tools, the most significant difference can be found in Country Strategy Papers (CSP). They are used as the planning tool for financial assistance, stretching over for a 7-year period. On the other hand, Multi-Country Strategic Papers (MCSP) are defining priorities at the regional levels. The process of determining the action programmes starts with the opinion of the IPA committee, shaping the implementing acts, which need to be adopted by the European Commission. By adopting the implementing acts, the strategyplanning documents are further translated into the proposals for actions. According to Maleti \& Kandija (2017), IPA-financed reforms should offer citizens improved possibilities and enable the growth of standards comparable to those of EU residents. 
Table 1. IPA II financial assistance for the period from 2014-2020 by country

\begin{tabular}{|l|c|c|c|c|c|c|}
\hline Country & $\mathbf{2 0 1 4}$ & $\mathbf{2 0 1 5}$ & $\mathbf{2 0 1 6}$ & $\mathbf{2 0 1 7}$ & $\mathbf{2 0 1 8 - 2 0 2 0}$ & Total \\
\hline Albania & 83.7 & 86.9 & 89.7 & 92.9 & 296.3 & 649.5 \\
\hline Bosnia and Herzegovina & 75.7 & 39.7 & 47 & 74.8 & 314.9 & 552.1 \\
\hline Northern Macedonia & 85.7 & 88.9 & 91.6 & 94.9 & 303.1 & 664.2 \\
\hline Kosovo & 83.8 & 85.9 & 88.7 & 91.9 & 295.2 & 645.5 \\
\hline Montenegro & 39.6 & 35.6 & 37.4 & 39.5 & 118.4 & 270.5 \\
\hline Serbia & 189.7 & 190.9 & 194.8 & 197.9 & 201.8 & 975.1 \\
\hline Turkey & 195.1 & 201.4 & 207.9 & 215.4 & 688.2 & 1508 \\
\hline Multi-user programmes & 348 & 365 & 390 & 410.4 & 1445.3 & 2958.7 \\
\hline
\end{tabular}

Source: European Commission (2020c)

\subsection{Implementation of the IPA II 2014-2020 in B\&H, Kosovo, and Turkey}

In the period from 2014 to 2020 , a total of 2705.6 million EUR was invested in the three analyzed countries, as presented in Table 2.

Table 2. IPA II funds allocated to B\&H, Kosovo, and Turkey in the period 2014-2020

\begin{tabular}{|l|c|c|c|c|c|c|}
\hline Country & $\mathbf{2 0 1 4}$ & $\mathbf{2 0 1 5}$ & $\mathbf{2 0 1 6}$ & $\mathbf{2 0 1 7}$ & $\mathbf{2 0 1 8 - 2 0 2 0}$ & TOTAL \\
\hline Bosnia and Herzegovina & 75.7 & 39.7 & 47 & 74.8 & 314.9 & 552.1 \\
\hline Kosovo & 83.8 & 85.9 & 88.7 & 91.9 & 295.2 & 645.5 \\
\hline Turkey & 195.1 & 201.4 & 207.9 & 215.4 & 688.2 & 1.508. \\
\hline Total & 354.6 & 327 & 343.6 & 382.1 & 1.298 .3 & 2.705 .6 \\
\hline
\end{tabular}

Source: European Commission (2020a)

\subsection{Data distribution normality check}

As to define which techniques are necessary while processing the data, the normality of data distribution should be tested. Besides the asymmetry (skewness) and roundness, flattening (kurtosis) is often used to evaluate the normality of distribution, whereas the most commonly used method for testing the normality distribution is the KolmogorovSmirnov test. The Kolmogorov-Smirnov test represents a statistical procedure for checking the validity and compatibility of a given distribution of the frequencies compared to the hypothetical distribution. This test serves to test the normality of distribution while comparing the empirical and theoretical distribution.

As shown in Table 3, the values of arithmetic mean, standard deviation, and some other parameters were obtained where the most important of them are skewness and kurtosis because their values can be used to check the deviation between empirical and normal distribution. The value of skewness is 2.238 , with the statistical error of .580, and the value of kurtosis is 6.10 , with the statistical error of 1.121, which shows that the distribution has a significant difference from the normal curve. 


\section{Journal of Contemporary Management Issues}

Table 3. Descriptive parameters

\begin{tabular}{|c|c|c|c|c|}
\hline \multirow{2}{*}{\begin{tabular}{|l|} 
\\
Total_IPA II
\end{tabular}} & & & Statistic & Std. Err \\
\hline & \multicolumn{2}{|l|}{ Mean } & 180.373 & 42.8717 \\
\hline & \multirow{2}{*}{$\begin{array}{l}95 \% \text { Confidence } \\
\text { Interval for Mean }\end{array}$} & Lower Bound & 88.423 & \\
\hline & & Upper Bound & 272.324 & \\
\hline & \multicolumn{2}{|l|}{$5 \%$ Trimmed Mean } & 159.976 & \\
\hline & \multicolumn{2}{|l|}{ Median } & 91.900 & \\
\hline & \multicolumn{2}{|l|}{ Variance } & 27569.779 & \\
\hline & \multicolumn{2}{|l|}{ Std. Deviation } & 166.0415 & \\
\hline & \multicolumn{2}{|l|}{ Minimum } & 39.7 & \\
\hline & \multicolumn{2}{|l|}{ Maximum } & 688.2 & \\
\hline & \multicolumn{2}{|l|}{ Range } & 648.5 & \\
\hline & \multicolumn{2}{|l|}{ Interquartile Range } & 139.7 & \\
\hline & \multicolumn{2}{|l|}{ Skewness } & 2.238 & .580 \\
\hline & \multicolumn{2}{|l|}{ Kurtosis } & 6.100 & 1.121 \\
\hline
\end{tabular}

Table 4 shows the results of normality of distribution, according by Kolmogorov and Smirnov. The Statistic column shows the data, which represents the rate of deviation from the normal standard rate. In our case, the value of that rate is 0.236 , and the Sig. column represents the relevance of determining deviation from the initial value of 0.0. Since the value of Sig. column, when translated to SPSS, is less than 0.01 , we can conclude that distribution statistically significant deviates from the normal curve on level of significance from 0.01 .

Table 4. Tests of normality

\begin{tabular}{|l|c|c|c|c|c|c|}
\hline \multirow{2}{*}{} & \multicolumn{3}{|c|}{ Kolmogorov-Smirnova $^{\text {a }}$} & \multicolumn{3}{c|}{ Shapiro-Wilk } \\
\cline { 2 - 7 } & Statistic & df & Sig. & Statistic & df & Sig. \\
\hline IPA II & .236 & 15 & .000 & .743 & 15 & .000 \\
\hline
\end{tabular}

a. Lilliefors Significance Correction

The result of the curve's normal probability, Normal Q-Q Plot, shows that observed values are not exactly positioned near the straight line, which would be expected from the normal distribution. On the other hand, the curve shown on Detrended
Normal Q-Q Plot represents the difference between the reference and the targeted value of normal distribution, or deviation of observed results from the horizontal line, which is in this case, the normal distribution (see Figure 1). 

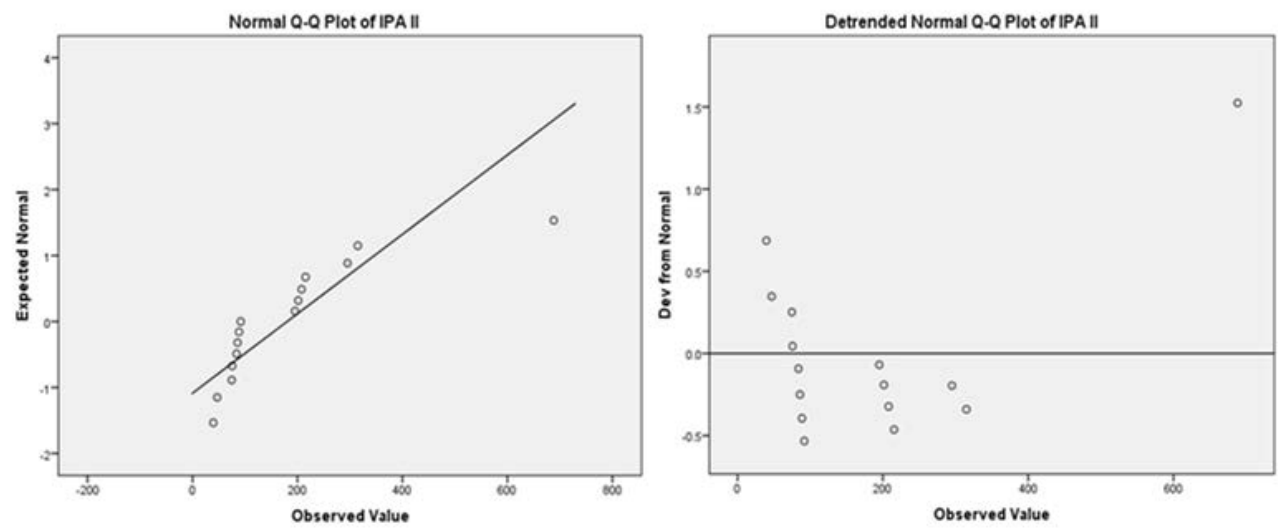

Figure 1. Normal and detrended normal Q-Q plots of IPA II

The same conclusion is supported by the following boxplot (see Figure 2), as well as other significant atypical points. These cases are above and below from the upper and lower lines, shown by the boxplot.

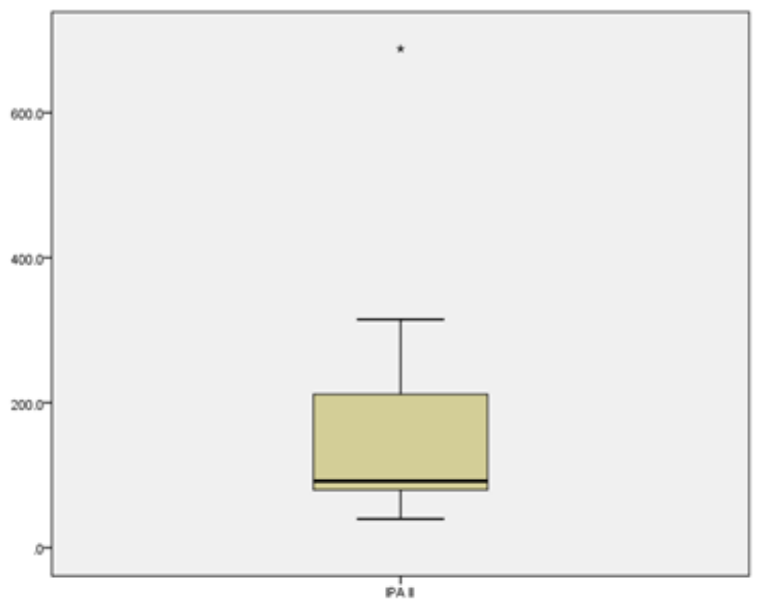

Figure 2. Boxplot of IPA II

Consequently, the following hypothesis is proposed:

Hypothesis 1: It is assumed that there is a correlation between IPA II fund values and previously defined sectors in Bosnia and Herzegovina, Kosovo, and Turkey.

To test the hypothesis, we use the Spearman's rho coefficient of correlation (see Table 5). The intensity of correlation might be based on the following criteria: the correlation is small (or insignificant) if the value of $r=0.10-0.29$, the correlation is average (or medium) if the value of $r=0.30$ -0.49 , and the correlation is large (significant) if the value of $r=0.50-1.00$. Table 5 shows that the results show an average positive correlation between IPA II and sector 


\section{Journal of Contemporary Management Issues}

variables $(\mathrm{r}=0.397)$. Therefore, IPA II fund values are correlated with previously stated variables. The significance of 0.000 supports the hypotheses.

Table 5. Spearman's rho - correlation or connection between IPA II and sectors

\begin{tabular}{|l|l|l|c|c|}
\hline & Variables & & IPA II & sectors \\
\hline \multirow{4}{*}{ Spearman's rho } & \multirow{2}{*}{ IPA II } & Correlation Coefficient & 1.000 & $.397^{* *}$ \\
\cline { 3 - 5 } & & Sig. (2-tailed) &. & .000 \\
\cline { 2 - 5 } & \multirow{2}{*}{ sectors } & Correlation Coefficient & & 1.000 \\
\cline { 3 - 5 } & & Sig. (2-tailed) & &. \\
\hline
\end{tabular}

${ }^{* *}$ Correlation is significant at the 0.01 level (2-tailed)

Further analysis focuses on the potential differences among the analysed countries, in their access to IPA II funds. We start the analysis by examining the following hypothesis:

Hypothesis 2: It is assumed that there is no difference in accessing the IPA II funds among countries.
Differences between Bosnia and Herzegovina and the Republic of Kosovo are presented by Table 6. Mann-Whitney test is used to convert the given values into the ranks for both groups and testing if the ranks between the groups are significantly different (see Table 7).

Table 6. Mann-Whitney test - sum of ranks

\begin{tabular}{|l|l|c|c|}
\hline & Country & Mean Rank & Sum of Ranks \\
\hline \multirow{2}{*}{ IPA II } & Kosovo & 203.01 & 33541.00 \\
\cline { 2 - 4 } & Bosnia and Herzegovina & 200.70 & 20023.50 \\
\hline
\end{tabular}

Table 7. Mann-Whitney test

\begin{tabular}{|l|c|}
\hline & IPA II \\
\hline Mann-Whitney U & 21034.000 \\
\hline Wilcoxon W & 34525.000 \\
\hline Z & -1.567 \\
\hline Asymp. Sig. (2-tailed) & .117 \\
\hline Exact Sig. [2*(1-tailed Sig.)] & $.151^{\mathrm{b}}$ \\
\hline
\end{tabular}

Grouping variable: Country

a. Not corrected for ties

If we observe the results shown in Table 7, we can notice that the value of the MannWhitney test is 21034.00 , with the significance value if 0.117 . Based on this result, it can be concluded there is no difference in IPA funds among Bosnia and Herzegovina and Kosovo.
Differences between Bosnia and Herzegovina and Turkey are presented by Table 8 . The same procedure has been applied, as in the previous case, with Table 9 presenting the results of statistical testing of differences. 
Table 8. Mann-Whitney test - sum of ranks

\begin{tabular}{|l|l|c|c|}
\hline & Country & Mean Rank & Sum of Ranks \\
\hline \multirow{2}{*}{ IPA II } & Turkey & 211.00 & 37654.50 \\
\cline { 2 - 4 } & Bosnia and Herzegovina & 299.40 & 211876.50 \\
\hline
\end{tabular}

Table 9. Mann-Whitney test

\begin{tabular}{|l|c|}
\hline & IPA II \\
\hline Mann-Whitney U & 22987.000 \\
\hline Wilcoxon W & 43561.000 \\
\hline Z & -2.786 \\
\hline Asymp. Sig. (2-tailed) & .100 \\
\hline Exact Sig. [2*(1-tailed Sig.)] & $.131^{\mathrm{b}}$ \\
\hline
\end{tabular}

Grouping variable: Country

a. Not corrected for ties

If we observe the results shown in Table 9, we can notice that the value of the MannWhitney test is 22987.00 , with the significance value of 0.100 . Based on this result, it can be concluded there is no difference in IPA funds among Bosnia and Herzegovina and Turkey.

Table 10. Mann-Whitney test -sum of ranks

\begin{tabular}{|l|l|c|c|}
\hline & Country & Mean Rank & Sum of Ranks \\
\hline \multirow{2}{*}{ IPA II } & Kosovo & 202.02 & 34234.00 \\
\cline { 2 - 4 } & Turkey & 199.80 & 29998.50 \\
\hline
\end{tabular}

Table 11. Mann-Whitney test

\begin{tabular}{|l|c|}
\hline & IPA II \\
\hline Mann-Whitney U & 24444.000 \\
\hline Wilcoxon W & 38761.000 \\
\hline Z & -1.777 \\
\hline Asymp. Sig. (2-tailed) & .115 \\
\hline Exact Sig. [2*(1-tailed Sig.)] & $.151^{\mathrm{b}}$ \\
\hline
\end{tabular}

Grouping variable: Country

a. Not corrected for ties
Differences between Turkey and the Republic of Kosovo are presented by Table 10, while Table 11 presents the results of the statistical testing, conducted with the same methodology, as in the two previous cases. 


\section{Journal of Contemporary Management Issues}

If we observe the results shown in Table 11, we can notice that the value of the Mann-Whitney test is 24444.00 , with the significance value of 0.115 . Based on this result, we can conclude that there is no difference in IPA funds among countries of Turkey and the Republic of Kosovo. Therefore, Hypothesis 2 is confirmed, as well. We can notice that, based on the obtained results, there are similarities in the comparisons between Turkey and the Republic of Kosovo, as well as between Bosnia and Herzegovina and the Republic of Kosovo.

\section{CONCLUSION}

European Union is one of the largest markets for all three countries, which were part of our research. Besides the opportunity to export to new markets more freely, which was possible by signing the Stabilization and Association Agreement between EU and Bosnia and Herzegovina and Kosovo, the IPA instrument represents another way to boost infrastructure and the overall economic development in beneficiary countries.

This study shows a high importance of the IPA II instrument for Bosnia and Herzegovina, Kosovo, and Turkey. Through this fund, the European Union has succeeded in providing the necessary technical and financial assistance to candidate countries, as well as to potential candidates, encouraging their growth and sustainable development. In addition, the funds from IPA II are invested in sectoral policies, based on strategic documents and action plans. With the continuous investments through the IPA instrument in the last decade, the European Union has shown a great effort to increase the living standards in beneficiary countries and has striven to enable to achieve the same standards comparable to those in the EU. IPA instruments bring countries closer to the EU integration, streghtening their competitiveness and embracing new economic possibilities.

It is also concluded that the investments corresponded to the specific needs of each of the priority areas and that they differed in the analyzed countries. Furthermore, we can conclude that different instruments of the EU can enable the development of targeted policies that are adjusted to individual partner country's needs, which implies that there has to be a tight connection among the admission process, obligations, and requests that need to be fulfilled in the process of negotiation, when it comes to the IPA II financial instrument, which is used to support the admission process.

Besides the relationship between instruments of IPA II and their impact on sectors in countries of Bosnia and Herzegovina, Kosovo, and Turkey, this study has also shown that there are no differences among these countries, using the same funds. This study represents initial research, analysing the potential impact of IPA II to the selected sectors, while the future research should focus on other important factors for this topic.

\section{REFERENCES}

1. Antonopoulos, E., \& Bachtler, J. (2014). The role of EU pre-accession assistance in the establishment of national coordination structures for EU funding: the case of Croatia. Journal of Contemporary European Research, 10(2), 185-202.

2. Battaglio Jr, R. P., \& Horasanli, M. (2018). Examining the effects of EU Instrument for Pre-accession Assistance (IPA) funding on perceptions of civil society among CSOs in 
Turkey: a case study of Batman province. Journal of European Integration 40(4), 393-409.

3. Belloni, R. (2009). European integration and the Western Balkans: lessons, prospects and obstacles. Journal of Balkan and Near Eastern Studies 11(3), 313-331.

4. Duran, M. (2014). The Absorption Capacity of Turkey for Its Use of the European Union Pre-Accession Assistance. Bogazici Journal, Review of Social, Economic and Administrative Studies 28(1), 69-93.

5. European Commission (2020a). Bosnia and Herzegovina - financial assistance under Instrument for Preaccession Assistance II (IPA II), available at: https://ec.europa.eu/neighbourhood-enlargement/enlargement-policy/ overview-instrument-pre-accession-assistance/bosnia-and-herzegovina-financial_en (accessed December 19, 2020).

6. European Commission (2020b). Kosovo - financial assistance under IPA II, available at: https://ec.europa. eu/neighbourhood-enlargement/enlargement-policy/overview-instrumentpre-accession-assistance/kosovo-financial-assistance-under_en (accessed December 19, 2020).

7. European Commission (2020c). Overview - Instrument for Preaccession Assistance, available at: https://ec.europa.eu/neighbourhoodenlargement/enlargement-policy/ overview-instrument-pre-accession-assistance en (accessed December 19, 2020).
8. European Commission (2020d) Turkey - financial assistance under IPA II, available at: https://ec.europa. eu/neighbourhood-enlargement/enlargement-policy/overview-instrumentpre-accession-assistance/turkey-financial-assistance-under_en (accessed, December 19, 2020).

9. Juncos, A. E. (2012). Member statebuilding versus peacebuilding: the contradictions of EU state-building in Bosnia and Herzegovina. East European Politics 28(1), 58-75.

10. Karakosta, C., Flouri, M., Dimopoulou, S., \& Psarras, J. (2012). Analysis of renewable energy progress in the western Balkan countries: Bosnia-Herzegovina and Serbia. Renewable and Sustainable Energy Reviews 16(7), 5166-5175.

11. Loeb, S.J., Dynarski, S.M., McFarland, D.A., Morris, P., Reardon, S.F., \& Reber, S.J. (2017). Descriptive Analysis in Education: A Guide for Researchers. NCEE 2017-4023. National Center for Education Evaluation and Regional Assistance.

12. Maletić, I., \& Kandžija, V. (2017). The accession process and IPA funds in Bosnia and Herzegovina - an opportunity for restructuring public spending and convergence towards the EU. Zbornik radova Ekonomskog fakulteta Sveučilišta u Mostaru (Special Issue 2017), 238-267.

13. Schober, P., Boer, C., \& Schwarte, L. A. (2018). Correlation coefficients: appropriate use and interpretation. Anesthesia \& Analgesi 126(5), 1763-1768. 


\title{
Journal of Contemporary Management Issues
}

\section{EFEKTI INSTRUMENATA PRETPRISTUPNE POMOĆI IPA II U BOSNI I HERCEGOVINI, NA KOSOVU I U TURSKOJ}

\begin{abstract}
Sažetak
S obzirom da je jedan od ciljeva Europske unije (EU) gospodarski razvoj i mogućnost integracije provođenjem temeljnih reformi kroz adekvatan strateški pristup, cilj ovog rada je utvrditi utjecaj politike EU i instrumenata pretpristupne pomoći (IPA fond) u međunarodnom poslovnom okruženju, s posebnim naglaskom na Bosnu i Hercegovinu, Kosovo i Tursku. Očito je da EU ne samo da pruža pomoć zemljama kandidatima, već doprinosi stabilnosti, sigurnosti i prosperitetu zemljama korisnicama. Međutim, ovakvim pristupom, odnosno instrumentima financijske podrške, EU nameće i određene promjene, pri čemu je pokretanjem IPA II programa nadmašila IPA I, uključujući pet prioritetnih područja kao ključne segmente razvoja. Već se pokazalo da je ovaj program potpore od velikog značaja za razvoj zemalja, obuhvaćenih istraživanjem. Ova studija, također, potvrđuje da IPA fondovi pomažu u političkim $i$ ekonomskim reformama država u tranziciji, pripremajući ih za prava i obveze koje proizlaze iz članstva u EU. U provedbi ovog rada korišteni su sekundarni podaci, dostupni na službenim web stranicama Europske Unije. Kvantitativnom analizom podataka potvrđena je hipoteza rada, pokazujući značajan utjecaj IPA II programa na definirane sektore u Bosni i Hercegovini, na Kosovu i u Turskoj.
\end{abstract}

Ključne riječi: EU, države u tranziciji, utjecaj, međunarodno poslovno okruženje, IPA II program 